UDC $712.4 / 712.3 / .7$

DOI https://doi.org/10.32851/2226-0099.2021.121.34

\title{
GROWING AND REPRODUCTION OF LAVANDULA HYBRIDA REV. UNDER THE CONDITIONS OF CLOSED SOIL IN THE SOUTH OF UKRAINE
}

\author{
Dementieva O.I. - PhD in Agricultural Sciences, \\ Associate Professor at the Department of Forestry and Landscape Architecture, \\ Kherson State Agrarian and Economic University \\ Boiko T.O. - PhD in Biology, \\ Associate Professor at the Department of Forestry and Landscape Architecture, \\ Kherson State Agrarian and Economic University
}

The article considers the peculiarities of cultivation and reproduction of Lavandula hybrid Rev. in closed soil in the south of Ukraine for its further application in city and landscape gardening.

It is widely used in medicine as an essential oil, which helps to make cosmetics, which confirms the rapid demand for it.

Studies have shown that interspecific hybrid Lavandula hybrida is the result of Lavandula angustifolia Mill. and Lavandula latifolia Medik crossbreeding.

It is noted that Lavandula hybrida displaces Lavandula angustifolia from agricultural fields for the following reasons: greater endurance to low winter temperatures, easiness to collect flowers mechanically (shrubs of more convenient shape); the most important feature of the plant is the ability to get more essential oil.

It is established that the cultivation of Lavandula hybrida takes place in private farms. Their number is insignificant; as a result, it is not possible to meet all the demand for this plant.

According to the literature sources and our own research, it has been established that lavender does not form seeds and has vegetative propagation. During the study, Lavandula hybrida cuttings were rooted in 2020-2021 in a greenhouse located on the territory of Kherson State Agrarian and Economic University. There were two stages of reproduction - in September 2020 and March 2021.

According to the results of an experiment on the rooting of Lavandula hybrida, it was found that higher percentage of rooting is observed during spring planting. Autumn rooting gave much lower percentage of survival. It is noted that woody cuttings have higher percentage of survival.

Lavandula hybrida deserves a wide introduction into agricultural production and landscaping in the Kherson region because of ecological and biological features, decorative and economic value, as well as economic efficiency of cultivation.

Key words: Lavandula hybrida Rev., vegetative propagation, rooting, cuttings.

Дементьєва O.I., Бойко T.O. Вирощування та розмноження Lavandula hybrida Rev. в умовах закритого трунту на півдні України

У статті розглянуто особливості вирощування та розмноження Lavandula hybrida Rev. в умовах закритого трунту півдня України для подальшого застосування в міському озелененні й садово-парковому будівництві. Відзначено ї̈ широке застосування в медицині, отриманні ефірної олії, за допомогою якої виготовлюють косметичні засоби, що підтверджує стрімкий попит на неї.

У ході досліджень було встановлено, щуо міжвидовий гібрид Lavandula hybrida з'явився внаслідок схрешення селекиіонерами двох видів: Lavandula angustifolia Mill. ma Lavandula latifolia Medik. 3'ясовано, шьо Lavandula hybrida витісняє Lavandula angustifolia із ciльськогосподарських полів із таких причин: більша витривалість низьких зимових температур, можливість краще й легше механічно збирати квіти (кущі більш зручної форми), а найвагомішою ознакою рослини є можливість отримати більше ефірної олії.

Установлено, щзо. вирощування Lavandula hybrida відбувається переважно в приватних господарствах. Їх кількість незначна, у результаті немає можливості задовольнити весь попит на культуру.

Згідно з літературними даними й власними дослідженнями встановлено, щз лавандин не утворює насіння, тому розмножується лише вегетативним шляхом. У ході дослі- 
дження було здійснено укорінення живиів Lavandula hybrida, щуо проводилося протягом 2020-2021 року в парнику, який розміщений на території Херсонського державного аграрно-економічного університету. Розмноження проводилося у два етапи - у вересні 2020 року й березні 2021 року.

За результатами проведеного досліду з укорінення Lavandula hybrida з'ясували, щуо більший відсоток приживлюваності живців культури спостерігається за весняної посадки. Осінне живцювання дало набагато мениий відсоток приживлюваності. Більший відсоток приживлюваності дають здерев'янілі живиі.

За еколого-біологічними особливостями, декоративною та господарською изінністю, а також економічною ефективністю вирошування Lavandula hybrida заслуговує широкого впровадження в сільськогосподарське виробництво й об'єкти озеленення Херсонської області.

Ключові слова: Lavandula hybrida Rev., вегетативне розмноження, вкорінення, живцүювання.

Setting of the problem. Nowadays the design of health and decorative garden and park facilities with the use of medicinal plants is intensively developing all over the world.

The introduction of perennial medicinal plants in urban landscaping is promising, as it supports the idea of environmental friendliness, beneficial effects on the environment, as well as the aesthetic complement of garden and park construction [1-3].

Reproduction and cultivation of the medicinal plant Lavandula hybrida Rev. for further use in landscaping is relevant in the south of Ukraine. The plants are suitable for use in flower beds, green borders, and as a supplement in small groups. It is important to note its widespread use in medicine, obtaining essential oil, which is used to make cosmetics, which confirms the rapid demand for it [4]. Climate change, the use of special techniques of agricultural technology have led to the expansion of areas suitable for growing lavender in particular in southern Ukraine [5].

Further expansion of the lavender cultivation area in Ukraine requires relevant scientific knowledge, which will allow developing effective technologies for its cultivation on large areas, ensuring the tourist attractiveness of the southern region of our country.

Analysis of recent research and publications. Peculiarities of growing Lavandula L. and its ecological and biological features have been studied by domestic and foreign scientists (A.P. Merkuryev, T.M. Latushkina, I.V. Belova, L.A. Kotyuk, D.B. Rakhmetov, L.V. Svidenko, M.F. Boyko, V.M. Derevyanko and others) [5-10]. A number of scientists investigated methods of reproduction technologies and lavender growing in the open ground [12-15].

It should be noted that researches of this culture were carried out in the conditions of southern coast of Crimea and the south of Ukraine where it was grown. However, in recent years, global climate change, including increasing temperature and decreasing rainfall led researchers the opportunity to conduct research features lavender cultivation, its reproduction and its cultivation in other agro-climatic conditions of Ukraine [11].

The aim of our study was to investigate the peculiarities of cultivation and reproduction of Lavandula hybrida in the closed soil of southern Ukraine.

Problem statement. The study was conducted during 2020-2021 on the territory of Kherson State Agrarian and Economic University. The studies used conventional methods of research in agriculture.

Ecological and biological features of Lavandula hybrida, as well as features of reproduction and cultivation of the plant in the closed soil of the south of Ukraine are analyzed.

An experiment on its vegetative propagation and rooting of different types of cuttings.

Presentation of the main research material. Lavender is the leading essential oil crop in Ukraine and the world. Natural essential oil and its raw materials are used in 
many branches of domestic industry and medicine. In addition, lavender is a valuable honey plant and a popular ornamental plant [11]. Distribution Lavandula hybrida in Ukraine will also contribute to increased production of cheaper essential oil. And will allow to collect more than $100 \mathrm{~kg}$ of lavender honey from one hectare [19].

The genus Lavandula L. belongs to the family Lamiaceae Lindl. Carl Linnaeus in the XVIII century identified four types of lavender [16]. Currently, according to various estimates and classifications, this genus includes from 25 to 39 species. Given the subspecies and interspecific hybrids, the total number of taxa within the genus Lavandula reaches 90 units $[17 ; 18]$.

Due to the high xerophytic properties of the Lavandula hybrida, this plants has been successfully used in ornamental planting many Mediterranean countries (Fig. 1).

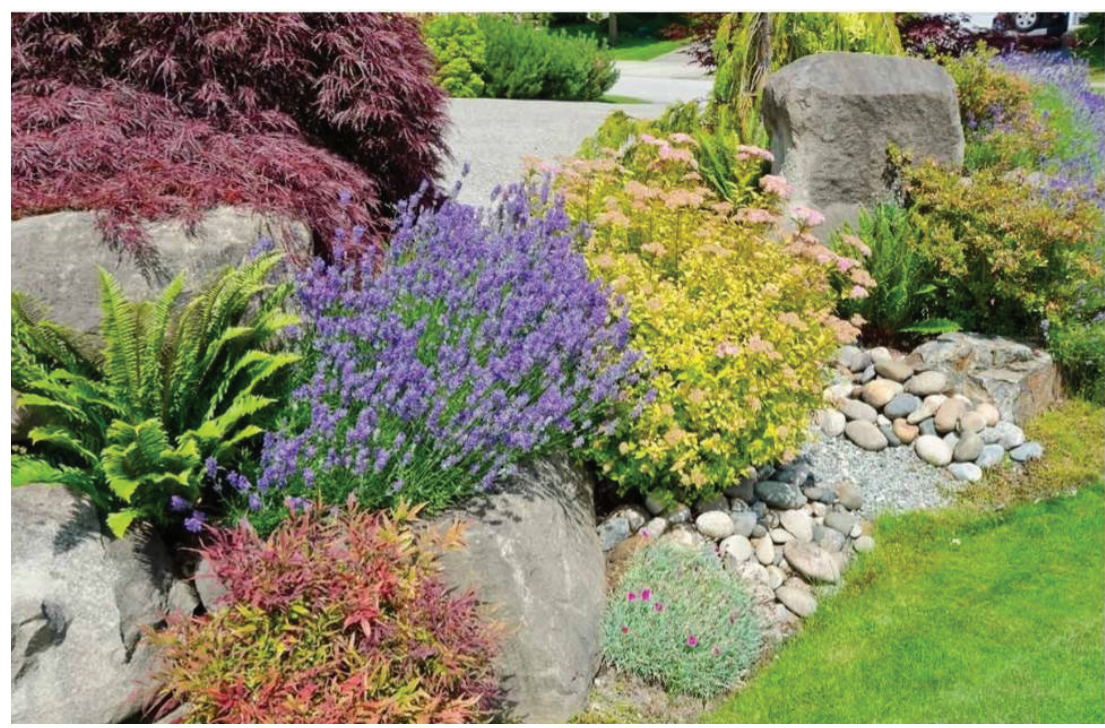

Figure 1. Use of Lavandula hybrida in rockeries

The study found that the interspecific hybrid Lavandula hybrida appeared as a result of crossbreeding of two species of Lavandula angustifolia Mill. and Lavandula latifolia Medik [5; 10].

In contrast to the parent forms, the interspecific hybrid Lavandula hybrida is an evergreen semi-shrub, a perennial plant about $90-100 \mathrm{~cm}$ in size. The root system is rodshaped, woody, well-developed, branched. The stems are branched. On shoots bloom spikes of small flowers, painted in shades of deep purple to white. The leaves are 5,5-6,0 cm long, about $0,9 \mathrm{~cm}$ wide, gray-green, fragrant. Flowers profusely from mid to late summer [20]. The plant is not demanding to soils, grows well on light or sandy soils or black earth [21].

Lavandula hybrida is frost-resistant, can withstand temperature decrease to $-25{ }^{\circ} \mathrm{C}$. Demanding to light. In the shaded areas reduced the content of essential oil. Excess moisture reduces the density of the stem plant, as a result of this plantation liquefies $[10 ; 21]$.

According to research I.I. Stetsenko [22], in the conditions of Crimea the content of essential oil in Lavandula hybrida exceeded Lavandula angustifolia in 4-5 times 
(170-250 kg / ha). The mass of the crude substance is 3-4\%. When growing Lavandula hybrida in the south of Ukraine, the content of essential oil was $205 \mathrm{~kg} / \mathrm{ha}$.

Lavandula hybrida displaces parental forms from agricultural fields due to greater endurance to low temperatures, the ability to better and easier to collect flowers mechanically (shrubs of more convenient shape). The most important feature of the plant is that it can produce more essential oil [10].

Lavandula hybrida also has high decorative properties. Densely leafy shrubs with a large number of peduncles look quite impressive in both single and group plantings. Borders with Lavandula are durable and easy to care for [23].

The most popular varieties of Lavandula hybrida are "Grosso", "Seal", "Impress Purple".

We found that in the south of Ukraine Lavandula hybrida is grown in private farms. Their number is insignificant and cannot satisfy all the demand for culture. Therefore, in the Kherson, Odessa and Mykolayiv regions the volumes of cultivation of the studied plant are gradually increasing [24; 25].

For industrial cultivation of Lavandula hybrida in the conditions of Kherson region the adapted planting material grown in the south of Ukraine is necessary.

The greatest growth of lavender is observed in the phase of flower stalks and in the phase of buds. After flowering, the growth rate of the plant will slows down [10].

Lavender does not form seeds. It can be propagated only by vegetative means cuttings of semi-woody shoots. During 2020-2021, we rooted Lavandula hybrida cuttings in the greenhouse of Kherson State Agrarian and Economic University. Reproduction was carried out in two stages in September 2020 and March 2021. In this method, the sprout is divided into parts containing lateral, apical or those and other buds. Under the created conditions additional roots will develop. Later formed separate plants [26].

In the first for propagationstage we selected woody and green cuttings up to $8-10 \mathrm{~cm}$. There are 3-5 leaves left on the sprout to feed the cuttings. The cut of a sprout is made necessarily oblique. As a result, 100 green cuttings and 100 woody cuttings were planted.

For a high percentage of cuttings rooting, the soil mixture in the greenhouse is well moistened. We dug the beds deeply, fed and leveled them. Rooting of cuttings took place in the closed ground. Planting material was planted at a distance of 5-8 cm.

Rooting cuttings of Lavandula hybrida lasted about 1-1,5 months (4-6 weeks). A sign of rooting cuttings is the appearance of new roots and leaves.

According to the results of an experiment on the rooting of Lavandula hybrida in 2020 , the following results were obtained: non-woody cuttings of $1 \mathrm{st}$ and 2 nd order took root by $4-5 \%$, woody cuttings of 5 th and 6 th order by $45-46 \%$.

When rooting cuttings in 2021, the survival rate of non-woody cuttings of the 1 st and 2 nd order was $43-47 \%$, woody cuttings of 5 and 6 order of $65-78 \%$.

According to the results of an experiment on the rooting of Lavandula hybrida, it was found that higher percentage of rooting is observed during spring planting. Autumn rooting gave much lower percentage of survival.

Conclusions and suggestions. Cultivation of Lavandula hybrida in the south of Ukraine is relevant today. The trend of its cultivation was borrowed from Western Europe. It is widely used in medicine as an essential oil, which helps to make cosmetics, which confirms the rapid demand for it. In addition, the decorative properties of Lavandula hybrida allow it to be actively used by green specialists for landscaping of modern landscapes, creating long-lasting beautiful flowering compositions.

Studies have shown that interspecific hybrid Lavandula hybrida is the result of Lavandula angustifolia Mill. and Lavandula latifolia Medik crossbreeding. 
It is noted that Lavandula hybrida displaces Lavandula angustifolia from agricultural fields for the following reasons: greater endurance to low winter temperatures, easiness to collect flowers mechanically (shrubs of more convenient shape); the most important feature of the plant is the ability to get more essential oil.

It is established that the cultivation of Lavandula hybrida takes place in private farms. Their number is insignificant; as a result it is not possible to meet all the demand for this plant.

During the study, Lavandula hybrida cuttings were rooted in 2020-2021 in a greenhouse located on the territory of Kherson State Agrarian-Economic University. There were two stages of reproduction - in September 2020 and March 2021.

According to the results of an experiment on the rooting of Lavandula hybrida, it was found that higher percentage of rooting is observed during spring planting. Autumn rooting gave much lower percentage of survival. It is noted that woody cuttings have higher percentage of survival.

Lavandula hybrida deserves wide introduction into agricultural production and landscaping in the Kherson region because of ecological and biological features, decorative and economic value, as well as economic efficiency of cultivation.

\section{REFERENCES:}

1. Антоненко Н.М., Бойко Т.О. Lavandula angustifolia "Hidcote" в озелененні приватної території Олешківського району Херсонської області. Modalități concep tuale de dezvoltare a științei moderne. 2020. Bucureşti, România. Volumul 1. C. $78-79$.

2. Boiko T., Dementieva O., Omelianova V., Strelchyuk L. Ornamental woody plants assortment expansion in landscaping the cities of Southern Ukraine. 20-th International multidisciplinary scientific geoconference SGEM 2020. 2020. P. 595-602.

3. Дементьєва О.І., Бойко Т.О. Особливості застосування багаторічних лікарських рослин в оформлені квітників міста Херсон. Таврійський науковий вісник, 2021. № 118. С. 333-340.

4. Марковська О.С., Стеценко I.I. Перспективна ефіроолійна культура для півдня України - Лавандин (Lavandula hibrida Reverenon) : матер. міжнар. наук.-практ. конф., м. Дніпро, 20 листопада 2019 р. Дніпро, 2019. C. 306.

5. Марковська О.С., Свиденко Л.В., Стеценко I.I. Порівняльна оцінка морфометричних показників і господарсько цінних ознак Lavandula angustifolia Mill. та Lavandula hybrida Rev. Наукові горизонти. 2020. № 02 (87). C. 24-31.

6. Меркурьев А.П., Немтинов В.И. Обоснование прогноза влияния абиотических факторов на урожайность соцветий и эфирного масла лаванды узколистной в Крыму. Научный журнал КубГАУ. 2014. № 99(05). С. 1-11.

7. Латушкіна Т.М. Клональне мікророзмноження і оздоровлення лаванди in vitro : автореф. дис. ... канд. с.-г. наук : 06.01.14. Сімферополь, 2006. 26 с.

8. Белова И.В. Физиолого-биохимические особенности адаптации розы эфиромасличной и лаванды узколистной к действию низких температур в предгорном Крыму : автореф. дисс. ... канд. с.-г. наук : 03.01.05. Краснодар, 2018. 24 с.

9. Котюк Л.А., Рахметов Д.Б. Алелопатичні особливості ароматичних рослин родини Lamiaceae Lindl. Інтродукція рослин. 2014. № 4. С. 68-76.

10. Эфиромасличные и лекарственные растения, интродуцированные в Херсонской области (эколого-биологические особенности и хозяйственно-ценные признаки) / В.Д. Работягов, Л.В. Свиденко, В.Н. Деревянко, М.Ф. Бойко. Херсон : Айлант, 2003. 238 с.

11. Кременчук P.I. Формування агроценозу лаванди вузьколистої за різних способів розмноження та технології вирощування в лісостепу : дис. ... канд. с.-г. наук : 06.01.09. Київ, 2020. 237 с. 
12. Кременчук P.I., Китаєв О.І. Оцінка морозостійкості лаванди вузьколистої. Сортовивчення та охорона прав на сорти рослин. 2017. Т. 13. № 2. С. 155-161.

13. Рудник-Іващенко О.І., Кременчук Р.І. Біологічні особливості рослин лаванди за насіннєвого способу розмноження у Лісостеповій зоні України. Наукові доповіді НУБіП Украӥни. 2018. № 4 (74). С. 1-14.

14. Свиденко Л.В., Кременчук Р.І. Стан і перспективи колекцій нових малопоширених субтропічних плодових культур, декоративних, ароматичних і лікарських рослин на півдні України. Генетичні ресурси рослин. 2015. № 17. С. 75-86.

15. Михальська Л.М., Швартау В.В., Кременчук Р.І. Фітомеліоративні властивості рослин Lavandula angustifolia L. за умов вирощування у зоні Лісостепу України. Вісник аграрної науки. 2018. № 10. С. 55-60.

16. Linnaei C. Species Plantirum, Exhibentes plantas rite cognitas, ad genera relatas cum differentis specificis, Nominibus Trivialibus, Synonymis Selectus, Locis Natalibus. Holmiae, 1753. Tomus II. P. 572-573.

17. Буш Н.А. Систематика высших растений. Москва : Учпедгиз, 1959. 536 с.

18. Mosyakin S.L., Fedoronchuk M.N. Vascular plants of Ukraine. A nomenclatural checklist. Kiev, 1999. 346 p.

19. Аринштейн А.И., Радченко Н.М., Серкова А.А. Расширение ассортимента эфирных масел за счёт внедрения новых эфироносов. Киев : 1996. С. 108-109.

20. Ефіроолійні рослини : навчальний посібник / M.І. Бахмат та ін. Кам'янець-Подільський, 2012. 321 с.

21. Мазурок І.Г., Котовська Ю.С., Про лавандин, попри карантин. Всеукраїнський мультимедійний журнал. 2020. № 8 (173). С. 74-75.

22. Марковська O.С., Стеценко I.I. Порівняльна характеристика лаванди вузьколистої (Lavandula angustifolia Mill.) і лавандину (Lavandula hybrida Reverenon) : міжнар. наук.-практ. інтер. конф., м. Дніпро, 6-7 лютого 2020 р. Дніпро, 2020. С. 361-365.

23. Свиденко Л.В. Особенности биологии и биохимии лавандина в условиях степной зоны юга Украины. Бюллетень Никитского ботанического сада. 2001. Вып. 83. С. 90-93.

24. Лавандин стає популярним серед фермерів не лише на Півдні. 2018. KURKUL : вебсайт. URL: https://kurkul.com/news/13716-lavandin-staye-populyarnimsered-fermeriv-ne-lishe-na-pivdni (дата звернення: 16.03.2021).

25. Від «Маленької Голландії» до Провансу: історія успіху. веб сайт: URL: http://agro-yug.com.ua/archives/26530 (дата звернення: 20.03.2021).

26. Иванова 3.Я. Биологические основы и приемы вегетативного размножения древесных растений стеблевыми черенками. Киев : Наукова думка, 1982. 288 с. 